\title{
Cytotaxonomy, Heterochromatic Polymorphism and Natural Triploidy of a Species of Astyanax (Pisces, Characidae) Endemic to the Iguaçu River Basin
}

\author{
Daniel Luis Zanella Kantek ${ }^{1}$, Rafael Bueno Noleto ${ }^{1}$, Alberto Sérgio Fenocchio ${ }^{2}$ and Marta \\ Margarete Cestari ${ }^{1}$ \\ ${ }^{1}$ Laboratório de Citogenética Animal; Universidade Federal do Paraná; pastelson@yahoo.com; 81531-990; \\ Curitiba - PR - Brasil. ${ }^{2}$ Laboratório de Citogenética; Universidad Nacional de Misiones; 3300 Posadas - Misiones - \\ Argentina
}

\begin{abstract}
Cytogenetic analysis with Astyanax sp. D revealed a karyotype of $2 n=50$ with $2 M+26 S M+6 S T+16 A$, besides a triploid specimen showing $2 n=75$ chromosomes $(3 M+39 S M+9 S T+24 A)$. C-banding strongly stained the terminal regions of several SM-ST-A chromossomes. Two pairs of acrocentric chromosomes presented interstitial heterochromatin, this state being polymorphic and occuring due to possible paracentric inversions. The results obtained with the AluI restriction enzyme and $A_{3}$ chromomycin were similar to the $C$-banding. Relationships were proposed between Astyanax sp. D and A. scabripinnis, as well as considerations for a possible origin of the triploid specimen $(2 n=3 x=75)$. When comparing the present results with cytogenetic features of other endemic Astyanax species in the Iguaçu river (A. sp. B and C), a clear differentiation was observed between them, indicating cytogenetics as an important cytotaxonomic tool.
\end{abstract}

Key words: Cytogenetics; triploidy; paracentric inversion

\section{INTRODUCTION}

The genus Astyanax has received special attention due to its biological and cytogenetic characteristics, with cases where different populations of the same species demonstrate cytogenetic and morphological differences. This genus shows a broad karyotypic variability, being observed from $2 \mathrm{n}=36$ in A. schubarti (Morelli et al.,1983; Daniel-Silva and Almeida-Toledo, 2001) to $2 \mathrm{n}=50$ in other species of the genus (Souza and Moreira-Filho, 1995). Variations in the diploid number have been detected within single Astyanax species, as is the case of A. fasciatus (Morelli et al., 1983; Justi, 1993) and A. scabripinnis
(Moreira-Filho and Bertollo, 1991; Souza and Moreira-Filho, 1995; Néo et al., 2000; Alves and Martins-Santos, 2002).

According to Sampaio (1988), the Iguaçu river has at least six Astyanax species. These species received the denominations of Astyanax sp.A, B, C, D, E, F. Althugh they lack a valid scientific name, these species are considered as real taxonomic entities in the literature concerning the Iguaçu river (Severi and Cordeiro 1994; Agostinho and Gomes 1997; Kantek et al., 2003; Ingenito et al., 2004). Garutti and Britski (2000) described the ocurrence of Astyanax altiparanae in the river. The objective of this study was to cytogenetically characterize Astyanax sp.D from the first plateau

\footnotetext{
Autor for corresponce
} 
of the Iguaçu river (Paraná, Brasil), comparing with other taxa and reporting one more case of natural triploidy.

\section{MATERIAL AND METHODS}

Seven Astyanax sp. D specimens (5 males and 2 females) from the first plateau of the Iguaçu river, in the township of Piraquara (PR), were studied. The mitotic metaphases were obtained by the indirect method described by Fenocchio et al. (1991). C-banding was performed as described by Sumner (1972), while chromomycin $\mathrm{A}_{3}\left(\mathrm{CMA}_{3}\right)$ and the restriction endonuclease $A l u \mathrm{I}$ assays were done according to Schmid (1980) and Mezzanote et al. (1983), respectively.

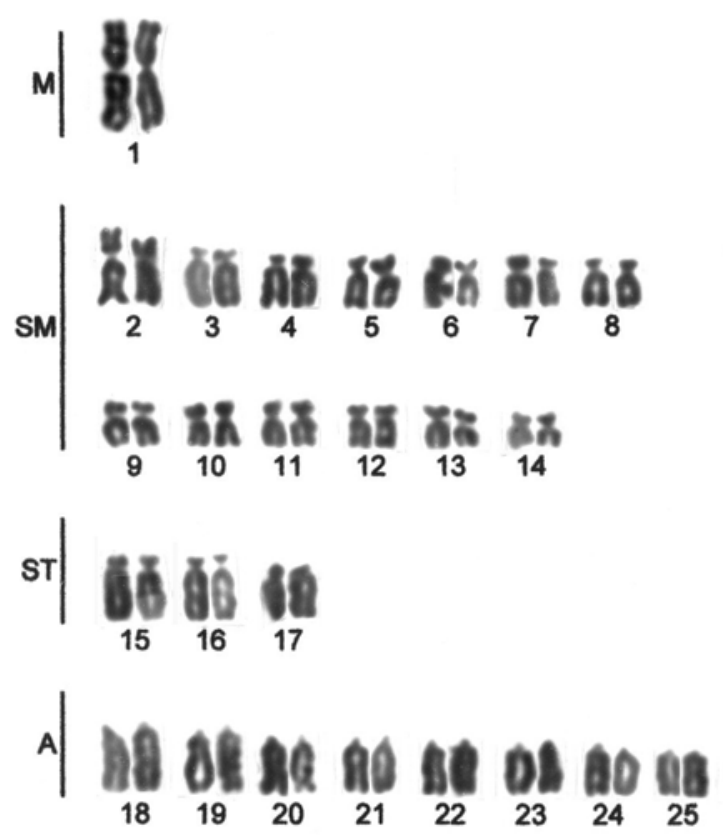

Figure 1 - Giemsa-stained karyotype of Astyanax sp. D.

\section{RESULTS}

The studied fish had a modal diploid number of 50 chromosomes, comprising 2 metacentric (M), 26 submetacentric (SM), 6 subtelocentric (ST) and 16 acrocentric (A) chromosomes, adding up to the fundamental number (FN) of 84 (Fig. 1). Heteromorphic sex chromosomes were not detected. The constitutive heterochromatin was detected (Fig. 2A, 3A) on weak little centromeric $\mathrm{C}^{+}$marks in some chromosomes and on large interstitial and terminal blocks located on the long arms of all ST chromosomes, on several A chromosomes and some SM chromosomes. Pairs 18 and 19 showed interindividual C-banding variations in the following situations: (1) both homologues with $\mathrm{C}^{+}$interstitial blocks; (2) one of the chromosomes with the $\mathrm{C}^{+}$terminal block and its homologue with an interstitial mark; (3) both homologues with $\mathrm{C}^{+}$terminal blocks (Fig. 2B). It was possible to observe a size heteromorphism of the heterochromatic blocks between homologues (Fig. 2A-pair 21), as well as heterochromatic marks that were located at a short distance above the telomere (Fig. 2A-pair 5). The number of Cbands was also variable. Figure $2 \mathrm{~A}$ shows only seven A chromosomes bearing such regions, while on Figure $3 \mathrm{~A}$ it is possible to visualize ten $\mathrm{A}$ chromosomes with C-bands. The $A l u \mathrm{I}^{+}$pattern was identical to the $\mathrm{C}$-banding distribution (Fig. 3A,B). A triploid specimen was also identified, with $2 \mathrm{n}=3 \mathrm{x}=75$ chromosomes: $3 \mathrm{M}+39 \mathrm{SM}+9 \mathrm{ST}+24 \mathrm{~A}$ (Fig. 4A). Its karyotype showed the same features observed for the diploid specimens. C-banding, $A l u \mathrm{I}$ and $\mathrm{CMA}_{3}$ data showed that triads 18 and 19 were formed by two identical chromosomes plus a third distinct chromosome (Fig. 4B, 5A,B). 


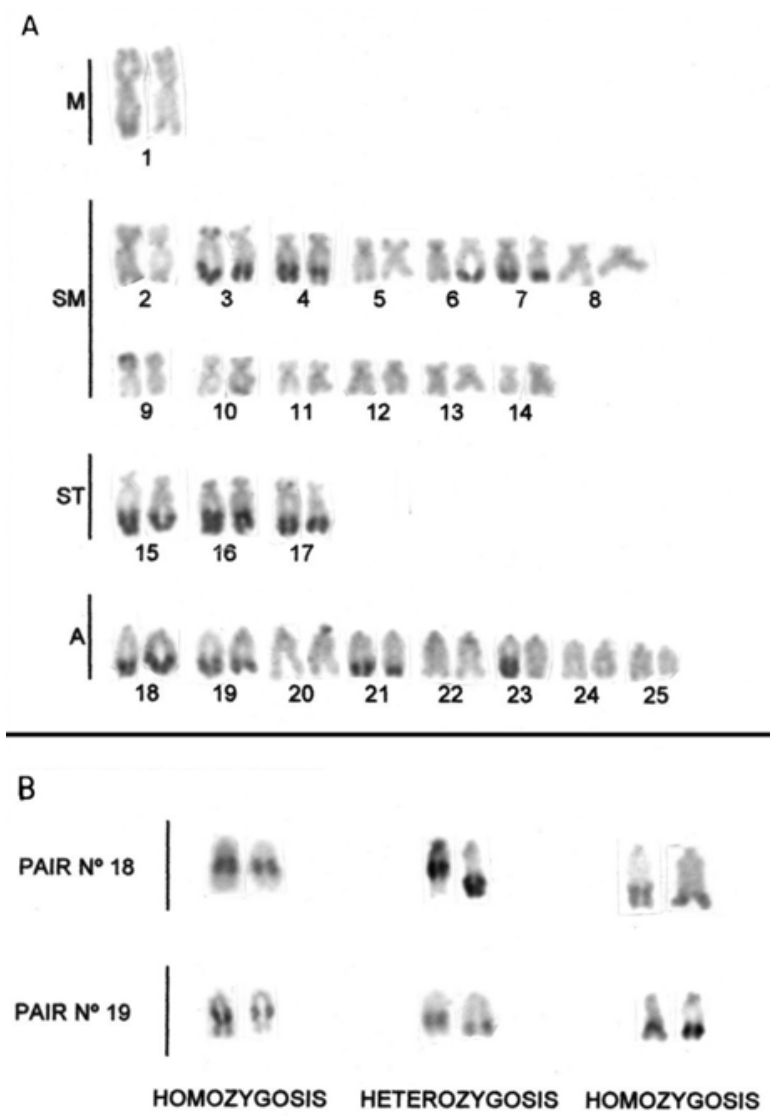

Figure 2 - A) C-banded karyotype of Astyanax sp. D; B) Chromosome pairs 18 and 19 showing heterochromatic blocks in heterozygosis and homozygosis.

\section{DISCUSSION}

The diploid number of $2 \mathrm{n}=50$ for Astyanax sp. D did not differ from those of most species of this genus, including A. scabripinnis (Moreira-Filho and Bertollo 1991; Maistro et al., 1998; Souza et al., 1996), Astyanax sp.C (Kantek et al., 2003), Astyanax sp.B (Fazoli et al., 2003) and A. altiparanae (Cenci and Margarido, 2003; Kantek et al., 2004). The C-banding pattern could be considered equilocal on the chromosomes. A possible explanation for this pattern would be based on the model proposed by Schweizer and Loidl (1987), which disserted on the orientation of the chromosomes during the meiotic interphase (Rabl orientation), allowing the transference of heterochromatin between equidistant positions of non-homologue chromosomes. The similarity between the $\mathrm{C}^{+}$blocks, also demonstrated by the
$A l u \mathrm{I}$ and $\mathrm{CMA}_{3}$ techniques, supported this hypothesis.

When comparing patterns of Astyanax. sp.D, some A. scabripinnis populations (Mantovani et al., 2000; Maistro et al., 2001) and A. janeiroensis (Carvalho et al., 2002) showed a similar Cbanding pattern. These species presented large terminal heterochromatic blocks located on the long arm of the ST and A chromosomes. The pattern obtained with $A l u \mathrm{I}$ was also similar for Astyanax sp. D and A. scabripinnis from the Cascatinha river (Maistro et al., 2001). However, other populations differed in C-band distribution (Maistro et al., 1998; Moreira-Filho and Bertolo, 1991), the same occurring with Astyanax sp. B. (Fazoli et al., 2003), Astyanax. sp.C (Kantek et al., 2003) and A. altiparanae (Cenci and Margarido, 2003; Kantek et al., 2004) from the Iguaçu river, which had less heterochromatin than Astyanax. sp. D. 

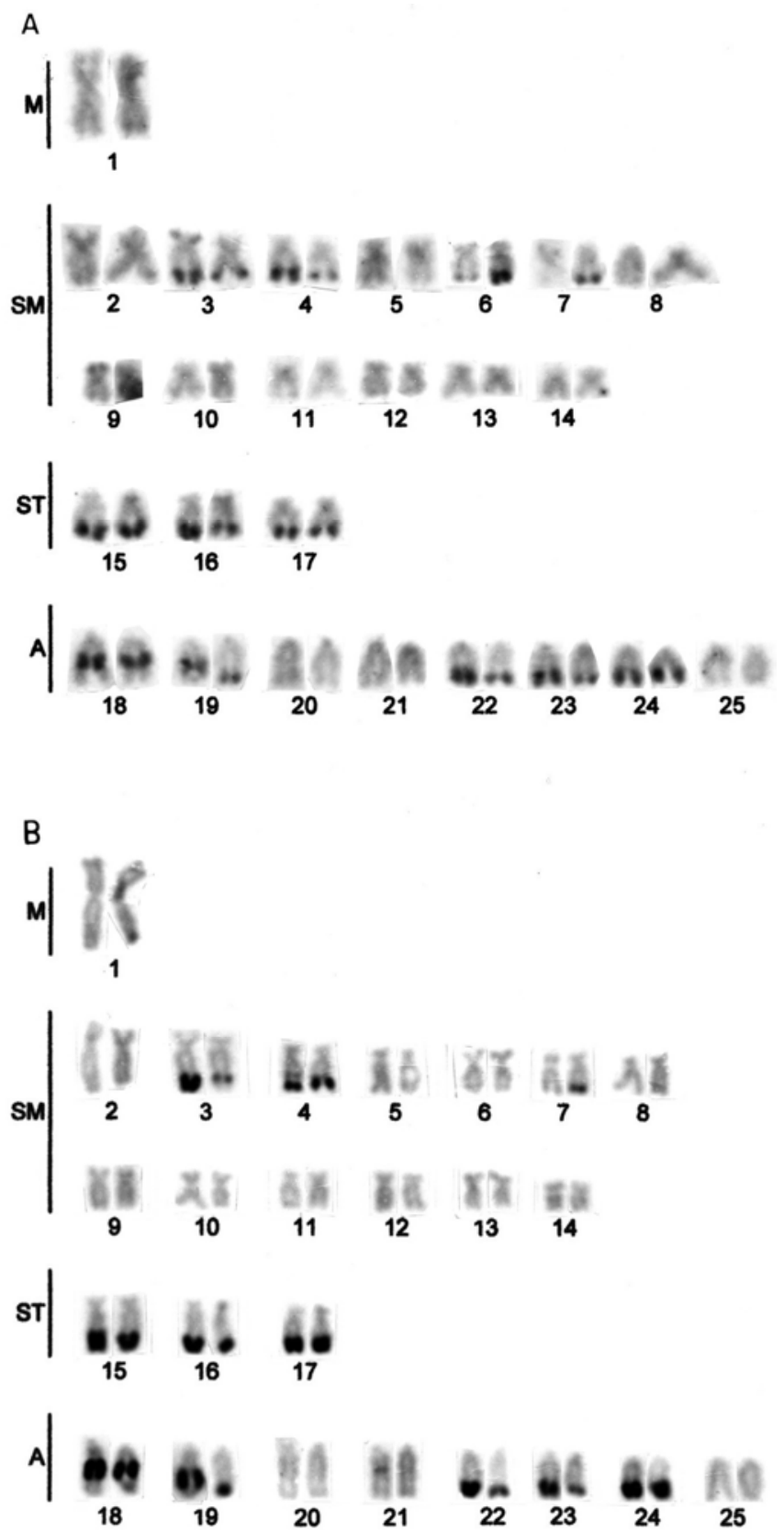

Figure 3 - Differential staining on only one specimen of Astyanax sp. D. A) C-banded karyotype; B) Restriction enzyme AluI-treated karyotype.

The C-band polymorphism on the $18^{\text {th }}$ and $19^{\text {th }}$ chromosome pairs of Astyanax sp.D seemed to be related to paracentric inversions. Such polymorphism was not detected in other Astyanax species thus far. A. janeiroensis (Carvalho et al., 2002) also showed interstitial $\mathrm{C}^{+}$blocks, but without a polymorphic condition.
$\mathrm{CMA}_{3}$ staining showed that $\mathrm{C}^{+}$regions of Astyanax sp. D were GC-rich, as occured in A. scabripinnis (Souza et al., 1996; Daniel-Silva, 1996). The differences in the amount of heterochromatin between homologues were also registered for A. scabripinnis (Mantovani et al., 2000; Maistro et al., 2000). 

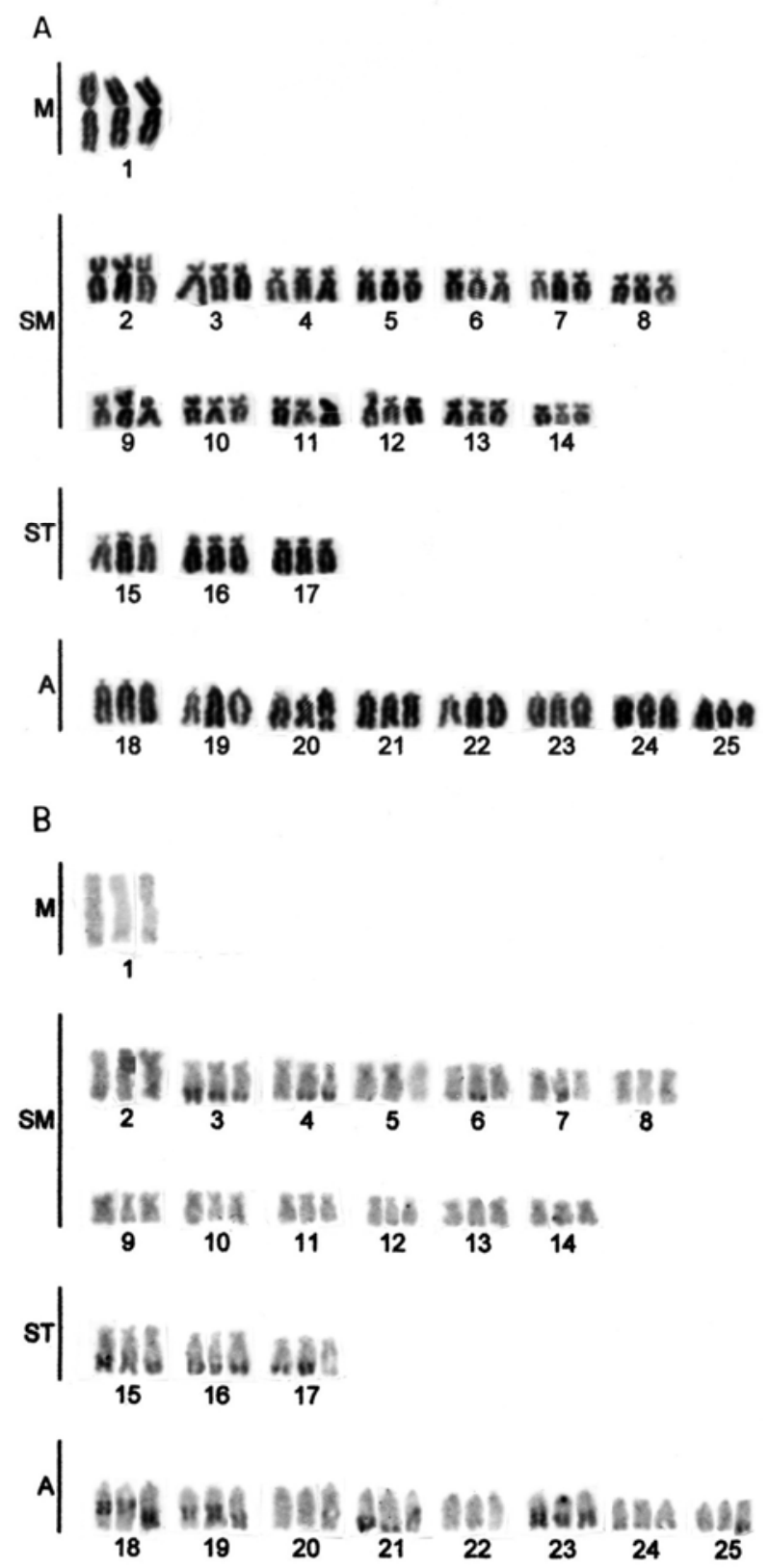

Figure 4 - A triploid Astyanax sp. D specimen. A) Giemsa-stained karyotype; B) C-banded karyotype

The identification key for Astyanax species elaborated by Eigenmann (1921) identified Astyanax sp. D as A. scabripinnis paranae. However, Sampaio (1988), through morphological measurements, considered these two fish forms as distinct species. The current diagnosis for $A$. scabripinnis (Eigenmann, 1921) was considered to be little specific as it joined many forms of Astyanax that inhabited headwaters, making it not informative for the taxonomy of this group. The high diversity recognized for this taxon would be a reflex of this flaw on its taxonomy. Many populations identified before as A. scabripinnis subspecies could now be considered new species. Future analysis would result in the recognition of other taxa (Bertaco and Malabarba, 2001). 


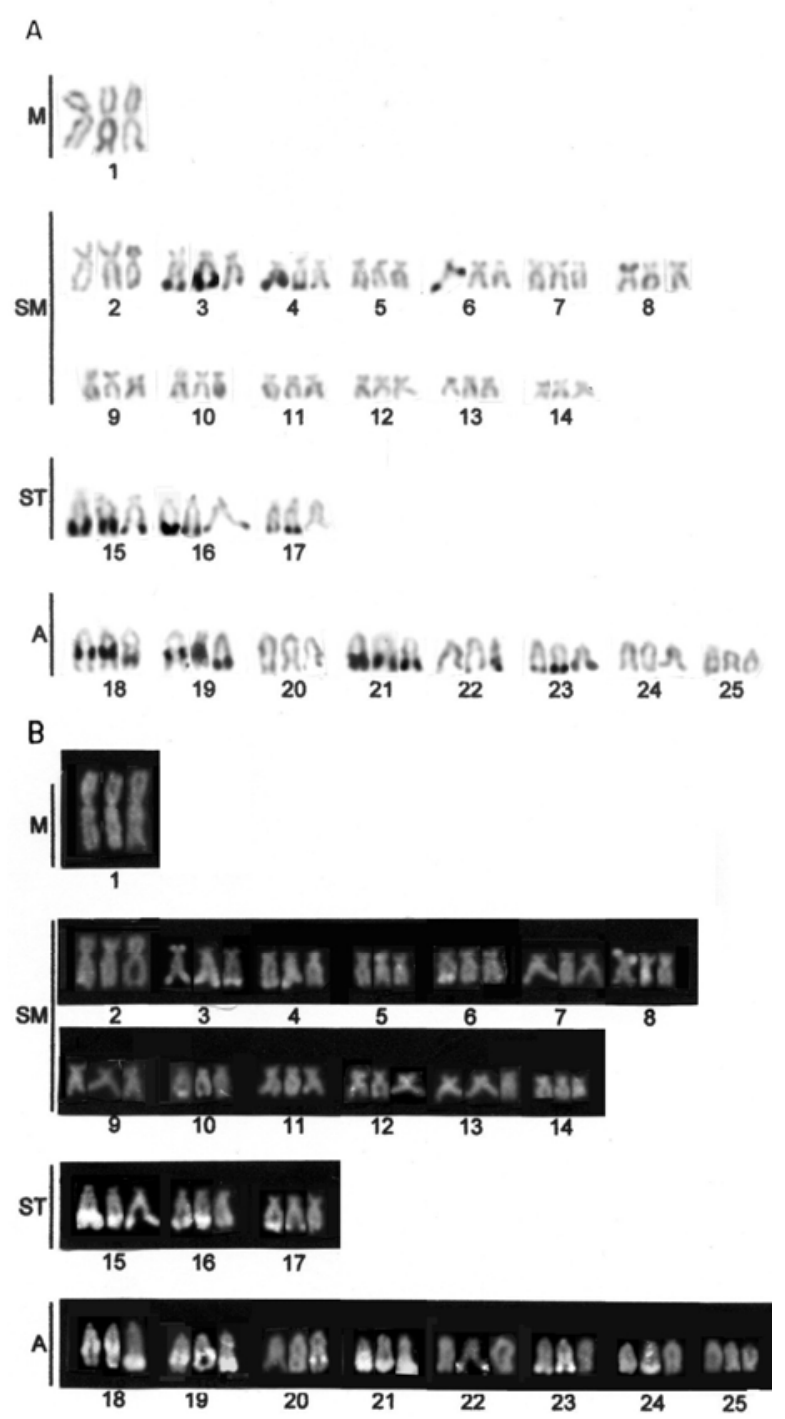

Figure 5 - Astyanax sp. D. triploid A) Restriction enzyme AluI-treated karyotype; B) $\mathrm{CMA}_{3}$ stained karyotype.

Astyanax, as well as most fishes, exhibited external fertilization, with the oocyte finishing the second mitotic division in the external medium (water), resulting in a non-disjunction of the sister chromatids (II meiosis) in adverse environment conditions (low temperatures, for example), producing one oocyte with $2 \mathrm{n}$ chromosomes (Fauaz et al., 1994).

Electrophoretic analysis of hybrids from the crossing of two carp species demonstrated that triploid individuals possesed two maternal alleles and only paternal allele (Tsukomo and Rigolino, 1993), supporting the hypothesis that the natural triploids came through a diploid egg $\mathrm{x}$ haploid sperm fertilization.

The identification of two identical chromosomes and one differentiated on the $18^{\text {th }}$ and $19^{\text {th }}$ triads of the triploid specimen (Figs. 4, 5) corroborated this hypothesis, which had been suggested for other fish species (Morelli et al., 1983; Almeida-Toledo et al., 1985; Giuliano-Caetano and Bertollo, 1990; Maistro et al., 1994). However, the alternative hypothesis, haploid egg $\mathrm{x}$ diploid sperm fertilization, could not be ruled out in the origin of the triploidy.

These results supported the proximity of the $A$. sp. $\mathrm{D}$ and A. scabripinnis groups. However presently, 
it would not be possible to differentiate between equal or distinct biological units. When confronting Astyanax sp. D with Astyanax sp. C (Kantek et al., 2003), Astyanax sp. B (Fazoli et al., 2003) and Astyanax altiparanae (Cenci and Margarido, 2003; Kantek et al., 2004) from the Iguaçu river, these species were clearly distinguishable by their cytogenetic features, showing the probable lack of gene flow between them as well as the importance of karyotypic data for the taxonomy of this fish group.

\section{ACKNOWLEDGMENTS}

We thank Vinicius Abilhoa from the Museu de Historia Natural Capão da Imbuia (Curitiba-PR) for the sample identification and Gil Caveira for translation of this paper. Financial support was provided by CNPq (National Council for Scientific and Technologic Development).

\section{RESUMO}

Análises citogenéticas em Astyanax sp. D evidenciaram $2 \mathrm{n}=50$ cromossomos e um cariótipo com $2 \mathrm{M}+26 \mathrm{SM}+6 \mathrm{ST}+16 \mathrm{~A}$. O bandamento $\mathrm{C}$ destacou as regiões teloméricas de diversos cromossomos SM-ST-A. Dois pares de cromossomos acrocêntricos possuem heterocromatina intersticial, sendo este estado polimórfico decorrente de prováveis inversões paracêntricas. O resultados obtidos com a enzima de restrição AluI e a Cromomicina $\mathrm{A}_{3}$ foram semelhantes aos do bandamento C. São propostas relações de parentesco entre Astyanax sp. D e Astyanax scabripinnis, bem como considerações sobre a possível origem do exemplar triplóide $(2 n=3 x=75)$. Ao comparar os resultados deste trabalho com outras espécies de Astyanax do Rio Iguaçu, estas espécies se tornam claramente distinguíveis, evidenciando a citogenética como uma importante ferramenta taxonômica.

\section{REFERENCES}

Agostinho, A.A. and Gomes, L. C. (1997), Reservatório de Segredo: bases ecológicas para o manejo. Eduem, Maringá, Brasil.
Almeida-Toledo, L.F.; Foresti, F. and Toledo-Filho, S.A. (1985), Spontaneous triploidy and NOR activity in Eigenmannia sp. (Pisces, Sternopygidae) from de Amazon basin. Genetica, 66, 85-88.

Alves, A.L. and Martins-Santos, I.C. (2002), Cytogenetics studies in two populations of Astyanax scabripinnis with $2 \mathrm{n}=48$ chromosomes (Teleostei, Characidae). Cytologia, 67, 117-122.

Bertaco, V. A. and Malabarba, L.R. (2001), Description of two new especies of Astyanax (Teleostei, Characidae) from headwater streams of Southern Brazil, with comments on the "A. scabripinnis species complex". Ichthyological Exploration of Freshwaters, 12, 221-234.

Carvalho, M.L.; Oliveira, C. and Foresti, F. (2002), Cytogenetic analysis of five species of the subfamily Tetragonopterinae (Teleostei, Characiformes, Characidae). Caryologia, 55, 181-188.

Cenci, M.A. and Margarido, V.P. (1999), Estudos citogenéticos comparativos de duas populações de Astyanax bimaculatus (PISCES, CHARACIDAE, TETRAGONOPTERINAE) coletados nas bacias dos rios Iguaçu e Piquiri. In: Anais do 45 Congresso Nacional de Genética, Gramado, Brasil.

Daniel-Silva, M.F.Z. (1996), Estudos citogenéticos comparativos em quatro espécies do gênero Astyanax (Pisces, Characidae). Masters Thesis. Universidade de São Paulo, SP, Brasil.

Daniel-Silva, M.F.Z. and Almeida-Toledo, L.F (2001), Chromosome R-banding pattern and conservation of a marker chromosome in four species, genus Astyanax (Characidade, Tetragonopterinae). Caryologia, 54, 209-215.

Eigenmann, C.H. (1921), The American Characidae. Memoirs of the Museum of Comparative Zoology, 43, 209-310.

Fauaz, G.; Vicente, V. and Moreira-Filho, O. (1994), Natural triploidy and B chromosomes in the neotropical fish genus Astyanax (CHARACIDAE). Revista Brasileira de Genética, 17, 157-163.

Fazoli, L.C.; Silva, V.A.B.; Portela-Castro, A.L.B and Júlio Jr, H.F. (2003), Chromosome characterization of Astyanax sp B (Characidae, Tetragonopterinae) an endemic species of the Iguaçu River, Paraná, Brazil. Cytologia, 68, 389-394.

Fenocchio, A.S.; Venere, P.C.; Cesar, A.C.G.; Dias, A.L. and Bertollo, L.A.C. (1991), Short term culture from solid tissues of fishes. Caryologia, 44, 161-166.

Garutti, V. and Britski, H.A. (2000), Descrição de uma nova espécie de Astyanax (Telestei: Characidae) da bacia do alto rio Paraná e considerações gerais sobre as demais espécies do gênero na bacia. Comum. Museu de Ciência e Tecnologia PUCRS Série Zoologia, 13, 65-88. 
Giulino-Caetano, L. and Bertollo, L.A.C. (1990), Karyotypic variability in Hoplerythrinus unitaeniatus (Pisces, Characiformes). II. Ocurrence of natural triploidy. Revista Brasileira de Genética, 13, 231237.

Ingenito, L.F.S.; Duboc, L.F. and Abilhoa V. (2004), Contribuição ao conhecimento da ictiofauna da bacia do alto rio Iguaçu, Paraná, Brasil. Arq. Ciênc. Vet. UNIPAR, 7, 23-26.

Justi, A.J. (1993), Caracterização cariotípica de populações de Astyanax fasciatus (Cuvier, 1819), Pisces, Characidae, em três bacias hidrográficas. Masters Thesis. Universidade Federal de São Carlos, São Paulo, Brasil.

Kantek, D.L.Z.; Fenocchio, A.S. and Cestari, M.M. (2003), Cytogenetic characterization and NOR polymorphism in Astyanax sp. C (Tetragonopterinae, Characidae) from First Plateau of Iguaçu River (Paraná State, Brazil). Cytologia, 68, 19-24.

Kantek, D.L.Z.; Domingues, M.S.; Artoni, R.F.; Noleto, R.B.; Cipriano, R.R.; Cestari M.M. (2004), Caracterização citogenética de Astyanax altiparanae (PISCES, TETRAGONOPTERINAE) da lagoa da fazenda Canguiri, bacia do alto rio Iguaçu (PR). In: Anais do X Simpósio de Citogenética e Genética de Peixes, Natal, Brasil.

Maistro, E.L.; Dias, A.L.; Foresti, F.; Oliveira, C. and Moreira, O. (1994), Natural triploidy in Astyanqx scabripinnis (Pisces, Characidae) and simultaneous ocurrence of macro B-chromosomes. Caryologia, 47, 233-239.

Maistro, E.L.; Oliveira, C. and Foresti, F. (1998), Comparative cytogenetic and morphological analysis of Astyanax scabripinnis paranae (Pisces, Characidae, Tetragonopterinae). Genetics and Molecular Biology, 21, 201-206.

Maistro, E.L.; Oliveira, C. and Foresti, F. (2000), Sympatric occurrence of two cytotypes of Astyanax scabripinnis (Characiformes, Characidae). Genetics and Molecular Biology, 23, 356-369.

Maistro, E.L.; Oliveira, C. and Foresti, F. (2001), Cytogenetic characterization of a supernumerary chromosome segment and of B-chromosomes in Astyanax scabripinnis (Teleostei, Characidae). Genetica, 110, 177-183.

Mantovani, M.; Abel, L.D.S.; Mestriner, C.A. and Moreira-Filho, O. (2000), Accentued polymorphism of heterochromatin and nucleolar organizer regions in Astyanax scabripinnis (Pisces, Characidae): tools for understanding karyotypic evolution. Genetica, 109, 161-168.
Mezzanote, R.; Bianchi,U.; Vanni, R. and Ferruci, L. (1983), Chromatin organization and restriction endonuclease activity on human metaphase chromosomes. Cytogenetics and Cell Genetics, 36, 562-566.

Moreira-Filho, O. and Bertollo, L.A.C. (1991), Astyanax scabripinnis (Pisces, Characidae): a species complex. Revista Brasileira de Genética, 14, 331-357.

Morelli, S.; Bertollo, L.A.C.; Foresti, F.; Moreira-Filho, O. and Toledo-Filho, A.S. (1983), Cytogenetic considerations on the genus Astyanax (Pisces, Characidae). I. Kariotypic variability. Caryologia, 36, 235-244.

Néo, D.M.; Moreira-Filho, O. and Camacho, J.P.M. (2000), Altitudinal variation for B chromosome frequency in the characid fish Astyanax scabripinnis. Heredity, 85, 136-141.

Sampaio, F.A.A. (1988), Estudos taxonômicos preliminares dos Characiformes (Teleostei, Ostariophysi) da Bacia do Rio Iguaçu, com comentários sobre o endemismo desta fauna. Masters Thesis. Universidade Federal de São Carlos, São Paulo, Brasil.

Schmid, M. (1980), Chromosome banding in Amphibia. IV. Diferentiation of GC- and AT-rich chromosome region in Anura. Chromosoma, 77, 83-103.

Schweizer, D. and Loidl, J. (1987), A model for heterochromatin dispersion and the evolution of Cband patterns. Chromosomes Today, 9, 61-74.

Severi, W. and Cordeiro, A.A.M. (1994), Catálogo de Peixes da Bacia do Rio Iguaçu. IAP/GTZ, Curitiba, Paraná, Brasil.

Souza, I.L. and Moreira-Filho, O. (1995), Cytogenetic diversity in the Astyanax scabripinnis species complex (Pisces, Characidade). I. Allopatric distribution in a small stream. Cytologia, 60, 1-11.

Souza, I.L.; Moreira-Filho, O. and Galetti Jr, P.M. (1996), Heterochromatin differentiation in the characid fish Astyanax scabripinnis. Brazilian Journal of Genetics, 19, 405-410.

Sumner, A.T. (1972), A simple technique for demonstrating centromeric heterochromatin. Experimental Cell Research, 75, 304-306.

Tsukamoto, R.Y. and Rigolino, M.G. (1993), Aplicação da biotecnologia à aqüicultura. In: Anais do $\mathrm{X}$ Encontro Brasileiro de Ictiologia, São Paulo, Brasil.

Received: March 11, 2005; Revised: October 03, 2005; Accepted: August 31, 2006. 